\title{
Women's Meanings of Peacebuilding in Post-Apartheid South Africa
}

\author{
Susan McKay \\ Nursing, Women's and International Studies \\ University of Wyoming \\ Cheryl de la Rey \\ Department of Psychology \\ University of Cape Town
}

\begin{abstract}
Although women's instrumentality in peacebuilding is internationally recognized, gendered meanings of peacebuilding are poorly understood. Our study was conducted to learn from a diverse group of South African women what peacebuilding means to them. Sixteen women gathered in Cape Town for a 2-day workshop that used feminist participatory methods to gather data about women's meanings of peacebuilding. All talk was audiotaped, transcribed, and analyzed for content pertaining to research questions and to identify thematic strands. For these workshop participants, peacebuilding is a process, relationship building is crucial to its effectiveness, and meeting basic human needs underlies its success. Women recognized their active involvement in peacemaking and peacebuilding and, occasionally, in peacekeeping and peace enforcing activities. They viewed their approaches often to be distinct from men's and believed the significance of their peacebuilding work is not adequately recognized within South African patriarchal society.
\end{abstract}

Internationally, recognition exists that women are instrumental in preventing and stopping armed conflict and building peace. Both during and after conflict, women have been integrally involved in peacebuilding processes, seeking solutions to problems such as resource degradation, demobilization and reintegration of former child soldiers, violence against women and children, effects of militarization, and sustainable economic, environmental, and political development. Women advo- 
cate for their greater inclusion in peacebuilding processes within community, national, and international nongovernmental organizations (NGO) and political bodies (Mazurana \& McKay, 1999). Importantly, women view their increased presence during peace negotiations as critically important (Anderlini, 2000).

A landmark event that called attention to the importance of women's peacebuilding occurred in Beijing, China, at the 1995 United Nations (UN) Fourth World Conference on Women. The conference's consensus document, the UN Platform for Action (PFA), included recommendations that advocated for women's increased involvement in conflict resolution, peace research, prevention of violence towards women, building cultures of peace, and reducing human rights abuse in conflict situations (McKay \& Winter, 1998; UN, 1996b). In addition, the Graça Machel Study (UN, 1996a; Wessells, 1998), which documented the effects of armed conflict upon children, identified women as active agents of peacebuilding and conflict resolution at grassroots levels and advocated for their increased participation at national, regional, and international levels (McKay, 1998). Four years later, a review of progress since the 1996 Graça Machel study was issued, again emphasized the critical roles of women in peacebuilding, both during and post-conflict (Machel, 2000, September). In October 2000, the UN Security Council unanimously adopted a resolution urging an increased role for women in UN peace promotion and post-conflict reconstruction. The resolution is the first in which the Council focused exclusively on war's effects on women and girls and acknowledged women as important actors in conflict resolution and nation rebuilding.

\section{Meanings of Peacebuilding}

Despite the frequency with which the term peacebuilding is used, its meaning is broad, and substantial differences exist about its products and processes. Scholars and practitioners ascribe to peacebuilding a wide variety of activities, relational behaviors, and structural changes (Boulding, 1995; Fisher, 1993; Galtung, 1976; International Alert, 2000; Lederach, 1995a; Mazurana \& McKay, 1999; Rigby, 1994; Ruecker, 2000). Boutros-Ghali's Agenda for Peace discussed peacebuilding in terms of "rebuilding the institutions and infrastructures of nations torn by civil war and strife and building bonds of peaceful mutual benefit among nations formerly at war" (UN, 1992, p. 8). Peace psychologists have described peacebuilding in terms of prevention, being proactive, problem solving, meeting human needs, and ending oppression and inequality (Abu-Saba, 1999; Christie, 1997; McKay, 1996; Wessells, 1992).

An example from Northern Ireland highlights the lack of precision about what constitutes peacebuilding. During the 1970s and 1980s, major dissension occurred between two Northern Ireland groups. One viewed peacebuilding as primarily 
mandating a structural approach and concentrated upon issues of justice and rights, equity and political issues. The other group believed peacebuilding primarily warranted a psycho-cultural approach and emphasized developing relationships between conflicting groups. Eventually, however, the group that preferred structural peacebuilding began dialogues about difficult structural problems as part of relationship building, and the group involved in structural work incorporated dialogic skills that enabled structural peacebuilding (Fitzduff, 1999). This divergence and eventual convergence in perspectives is noteworthy because it reflects similar differences between masculinist and feminist perspectives about peacebuilding (see discussions in de la Rey \& McKay, in press; Mazurana \& McKay, 1999; McKay \& Mazurana, 2001). Ultimately, effective peacebuilding requires multifaceted approaches.

\section{Feminist Meanings of Peacebuilding}

Mazurana and McKay (1999) used feminist analysis to examine women's meanings of peacebuilding at UN, grassroots, and NGO levels. They concluded that women's peacebuilding is culturally and contextually based and developed the following feminist definition:

Peacebuilding includes gender-aware and women-empowering political, social, economic, and human rights. It involves personal and group accountability and reconciliation processes which contribute to the reduction or prevention of violence. It fosters the ability of women, men, girls, and boys in their own cultures to promote conditions of nonviolence, equality, justice, and human rights of all people, to build democratic institutions, and to sustain the environment. (p. 9)

Women's peacebuilding, both during and in the aftermath of armed conflicts, typically occurs at community and regional levels although, increasingly, the influence of their peacebuilding initiatives is being felt nationally and internationally. To support women's community-based approaches, understanding is required about how peacebuilding is constructed and divergent ways cultures and people advance their own peacebuilding policies and projects (Mazurana \& McKay, 1999). Lederach (1995b) recognized that cultural knowledge is a key resource in both the creation and development of peacebuilding models and must be appropriate to a given setting. This respect for cultural knowledge embraces the indigenous knowledge of participants, their ways of being and doing, and their immediate situations, past heritage, and language.

Examples of women's cultural-specific approach to peacebuilding abound. Abu-Saba (1999) described how women worked to build bridges between factions and sects involved in the Lebanese civil war. In a related example, nearby, in Is- 
rael, a small group of women called "Four Mothers" developed peacebuilding initiatives to save their sons' lives and influence the Israeli government to pull the military out of Lebanon (McKay \& Mazurana, 2001). In response to peacebuilding needs within the Asian region, women's NGOs in the Philippines, Japan, and South Korea focused upon violence against women and achieving gender justice for comfort women. These young women were taken by the Japanese military during World War II from their homes and communities and abducted into sexual slavery (McKay \& Mazurana, 2001). Also, in South Korea, major emphases of women's peacebuilding are North Korea's nuclear threat, the presence of U. S. military bases, prostitution and violence toward women in conjunction with these bases, reunification of North and South Korea, and land mines within the demilitarized zone. In Ghana, where ethnopolitical warfare in the north occurred in the mid-1990s, much of the emphasis of women's peacebuilding is upon protection of human rights, economic stability, poverty reduction, and adequate housing (McKay \& Mazurana, 2001). In post-conflict Guatemala, critical peacebuilding issues are women's human rights in areas such as health, education, and social services and their marginalization within political process (Ruecker, 2000). In many parts of Africa, violence during war has legitimized post-conflict privatized violence, with escalated male violence toward women. Women in Africa, as elsewhere, know that freedom from such violence is essential in building peaceful societies. Therefore, an emphasis of women's peacebuilding is reducing violence and securing gender equity (Pillay, 2000).

\section{Women's Peacebuilding Within South Africa}

During the apartheid era, legislated racism in the form of apartheid policy systematically dispossessed Black people and privileged Whites. Until driven to change by mass resistance and widespread sanctions, the political system refused to compromise on White privilege. Divisiveness and intolerance were entrenched in all spheres of everyday life. During the 1980s and early 1990s, violent conflicts between the Nationalist Party government and the broad democratic movement increased. In 1994, after years of intensive negotiations, South Africa held democratic elections for the first time ever and, in the aftermath, democratic processes were developed.

In spite of radical reformation of government and social policy, violence continues to be an important concern for South Africans and a significant peacebuilding issue in this post-conflict society. Gender violence is of particular concern to South African women (Turshen, 1998). On International Women's Day 2000 , countrywide campaigns protested the high rate of sexual abuse and rape. Goldblatt and Meintjes (1998) observed that gender-related violence and inequalities mark the lives of the majority of Black South African women. Similarly, Zulu (1998) described today's democratic South African society as profoundly patriar- 
chal, women remaining among those most politically, socially, and economically marginalized. Women are oppressed through South African social structures and institutions, and violent acts such as rape, serious assault, and murder, which are reported in the media daily. Violence against women thus poses a serious obstacle to women's empowerment. Against this backdrop, women's involvement in peacebuilding is critical to ensure that stopping gendered violence and related feminist concerns remain on the post-conflict peacebuilding agenda.

\section{THE STUDY: \\ WOMEN AND PEACEBUILDING IN SOUTH AFRICA}

Women's peacebuilding and the meanings they attach to peacebuilding were the focus of a research project designed and implemented by co-investigators Cheryl de la Rey of the University of Cape Town, South Africa, and Susan McKay of the University of Wyoming, United States of America. ${ }^{1}$

\section{Purposes of the Study}

The study's central purpose was to bring together South African women leaders to discuss women's peacebuilding meanings and approaches and influences of gender and cultural variables. The major research questions formulated by the researchers were:

1. What methods and processes are used in women's peacebuilding work?

2. How do South African women who work to build peace view the meaning of peace?

Through this research, we hoped our findings could be used in other cultural contexts and provide groundwork for the development of a model for developing women's peacebuilding capacities. The study contributes to the UN Platform for Action goal of increasing women's capacities for peacebuilding as specified in strategic objective E.4: promote women's contributions to fostering a culture of peace (UN, 1996b).

\section{Methodology}

Our methodology, feminist participatory research, was designed to bring women and their perspectives to the center of the knowledge creation process and to have them articulate their points of view (Hall, 1992). Of central importance was

\footnotetext{
${ }^{1}$ Funding was provided by the International Development Research Center (IDRC) in Ottawa, a Canadian NGO with a mandate to mainstream gender perspectives within research.
} 
creating spaces for women's voices (de la Rey \& McKay, in press) and eliciting their perspectives. Participatory research incorporates the principles that inquiry should be experiential, participatory, and action oriented. Reason (1998) advocated the importance of a participative approach because it affirms the right of people to have a say in decisions affecting them and in the production of knowledge that purports to be about them. Feminist participatory research may involve participants in shaping the study format and data analysis (Reinharz, 1992); for our study, we assumed these responsibilities. Our approach maximized participant involvement in the research process and engaged them in decision making within a planned 2-day workshop format. Because of the participatory nature of the process, there is inherent risk that the researchers' agenda may not be fulfilled as intended.

\section{Selection of Participants}

A written call for nominations was sent to organizations in South Africa with peacebuilding interests. Eighteen nominations were received, and 16 women were invited. To avoid duplication in types of organizations, two were not included. The final group of 16 women was diverse in terms of race, ethnicity, religion, and geographic region. No one racial group was dominant. Women came from several regions of South Africa, specifically urban areas of Durban, Johannesburg, Cape Town, and the Western Cape. During the workshop, participants identified themselves as Jewish, Muslin, and Christian.

\section{Workshop Format}

The setting for the workshop was in a meeting hall in a residential elementary school, a venue that provided a quiet atmosphere for both plenary and breakout sessions. The overall structure of the workshop was developed in advance by members of the Advisory Committee, the two workshop facilitators, and de la Rey. Using a participatory model popular in South African workshops, the format was designed to encourage participant interaction, be flexible, and provide direction for answering research questions. During the workshop, participants engaged in experiential activities, small group discussions, and group brainstorming. Periodic consolidation of ideas and participants' evaluation of workshop processes resulted in refining and, sometimes, refocusing workshop direction.

Day One. The first day focused on meanings of peacebuilding. After participants discussed meanings that they attached to peacebuilding, the two workshop facilitators summarized and categorized the discourse into four broad categories: (a) basic needs, (b) individual and community peacebuilding, (c) values, and (d) processes. They then assigned participants to one of four subgroups to discuss one 
of the concepts and its relation to women's peacebuilding. Participants were asked to create a drawing that symbolized their assigned concept's relevance to peacebuilding. When the entire group reassembled, drawings from each subgroup were exhibited and explained, and the entire group then discussed how each concept was relevant to women's peacebuilding.

Day Two. Dialogue during most of the second day was about meanings of the terms peace enforcement, peacemaking, peacekeeping, and peacebuilding and women's involvement, or lack of involvement, in these processes. At the conclusion of the workshop, participants were asked what they would do within their own organizations to incorporate workshop ideas.

\section{Data Analysis}

All workshop talk, both small group and plenary sessions, was audiotaped and transcribed and constitutes the units for data analysis. In addition, drawings from Day One were visually analyzed for thematic content. Field notes and participants' evaluations provided additional data. We independently analyzed the data by using constant comparative analytic methods consistent with grounded theory. As co-investigators, we provided both an etic ("outside of phenomenon") perspective (McKay) and an emic ("inside of phenomenon) perspective (de la Rey). By carefully reading and rereading the transcripts, thematic categories emerged from the data. McKay hand-coded transcript data, and de la Rey used Nudist ${ }^{\odot}$ software for computer analysis of data. Content that informed research questions was grouped, organized by category, and analyzed. After completing data analysis, we compared analytic themes and examined data that related to research questions. Our analyses were highly congruent, increasing confidence in the reliability of our findings. In this article, we report findings that address our two research questions. We also include thematic analysis of participants' drawings that provide critical data about women's meanings of peacebuilding. ${ }^{2}$

\section{Research Findings ${ }^{3}$}

Of the two questions we report in this article, our first was partially answered whereas our second question was fully answered. The next section addresses these research questions. All quotations come from workshop transcripts.

\footnotetext{
${ }^{2}$ In a separate report, we discuss an important theme of this study, that peace is a gendered process (de la Rey \& McKay, in press).

${ }^{3}$ Because of the participatory nature of the workshop, we were unable to ensure in advance that each research question would be fully answered. In fact, data yield for our original three research questions varied. Thus, in this article we report on two research questions and not the third because it did not yield substantive thematic content.
} 
1. What methods and processes are used in peacebuilding work by women within the South African context?

Workshop participants repeatedly emphasized that their peacebuilding work within South Africa is important and that it should be recognized as such. Only occasionally did participants talk about peacebuilding in the context of changing societal structures. More often they advocated influencing the political, judicial and economic structural systems to be more effective gender-sensitive structures that thereby could facilitate peacebuilding. During their dialogues about the meanings of peacebuilding participants repeatedly emphasized that process is the core aspect of peacebuilding. Examples of their discussions about the importance of process are:

Process, how we go about achieving [peacebuilding], is as important as what we are trying to achieve.

Process takes time, patience, understanding, courage and commitment—staying the course, bearing it.

How we are growing is as important as what comes out.

Peacebuilding is the process to get to the goal.

It's [peacebuilding] recognition for the work we are doing, involvement, skills, linkages with non-formal and formal power, education, and making people aware of the bigger picture and being conscious of how [these processes] fit into the bigger picture.

Peacebuilding would be adapting structures of society to the values you profess. If you believe in communication, you make sure that every change you communicate, you will communicate in an honest open way ... so that in your work, you organize systems and structures where you allow communication and feedback. You put into place what you believe in.

Women said they should acknowledge as part of their self identities that "what I do is peacebuilding." They realized that too often they kept in the background and were not sufficiently active in peacebuilding. By taking initiative, being assertive, thinking big, taking responsibility, and using power, they could expand their influence. Further, participants thought women need to support, challenge, and trust each other in their peacebuilding work. They expressed appreciation for their vision and abilities to articulate peacebuilding processes and identified specific practices, such as networking and collaboration, areas of women's strength that they could continue to use within their own organizations. 


\section{Processes}

Peacebuilding processes that women identified were diverse and wide ranging, and focused predominantly on interactive communication methods and people-oriented peacebuilding processes. These included being team players and working together; reaching out to others' pain; developing awareness and involvement; being movers and shakers; working for change in culture; overcoming fear; compromising; collaborating; taking and giving space to and from men (taking up patriarchal space but giving men space to be involved, such as in rape prevention); learning to deal with the past and trusting again; recovering and rediscovering human agency; being the moral and spiritual center of families; awakening critical consciousness of people; bringing up children to respect others; building peace in communities; "looking inside" to one's emotional state by meditating, dancing and similar practices; listening; building partnerships; thinking peace; and nurturing the well-being of people.

\section{METHODS}

The methods participants identified to accomplish peacebuilding were concrete, pragmatic, and included multiple venues. These included networking; teaching; "acting as women" by using women's distinct strategies; organizing around issues women have in common; grassroots work; advocacy; lobbying; working within their own networks; engaging in funding; communicating via e-mail, fax, and Women's Net (Web site); using the word peace; positioning women within "houses of power" (i.e., military, government); and getting a peace strategy on South Africa's national agenda. Other strategies included safety promotion; community mediation; organizing within their communities; recognizing people in the field; involving women in the media; developing a healthy NGO sector; managing conflict and its origins; linking processes of peace enforcement; peacekeeping, peacemaking and peacebuilding and being involved in each of these processes; creating linkages outside of their own organizations; and developing "tool kits" for skills development.

2. How do women in peacebuilding activities view the meaning of peace within the South African context?

Meanings of peace were addressed continuously throughout the workshop. Peace was linked to values, spirituality, safety, nourishment, and to home, community, and the planet. Some participants viewed peace as a basic need in order that society be transformed. Among participants' statements about meanings of peacebuilding were: 
Peace nurtures and nourishes mankind.

Peace is part of our source.

A comfortable, safe place.

Peace is like maize, food for the people, food for the nation; we thrive on it.

Love keeps you in the peace process and gives staying power.

\section{Thematic Analysis of Drawings}

In this section we describe the drawings and then analyze their content. Images created in the four drawings symbolized different concepts about peacebuilding: basic needs, individual and community, values, and process. The drawings were unique, concrete, expressive, and startling in the clarity of symbolic expression. The descriptions of the drawings use participants' words to explain their symbolism.

1. Basic needs. The drawing created by this group to symbolize basic needs was a mealie (ear of sweet corn).

Peace is like maize, food for the nation! The green leaves represent our needs, which protect and nurture the inside. Inside the mealie are people (kernels of corn). When needs are satisfied, people are nurtured. Most of these needs are the same. You open a mealie and all those little seeds are the same, a representation of our common humanity. Needs, when satisfied, nurture and grow people and give rise to a number of other products - like mealie rice, maize flour, sweet corn, mealie meal, samp and maizena. Peace is like the mealie, food for the nation, for people, and we thrive on it. When basic needs are met, differences are very easy to live with-we can celebrate our differences. Lack of satisfaction of basic needs creates wars. Traditionally women make maize flour and mealie rice; women are the peacemakers.

2. Individual and community. This group's drawing, intended to symbolize individual and community peacebuilding, showed a large and colorful umbrella. Hands of various colors were shown holding the stem of the umbrella, keeping it upright and open. At the base of the drawing were representations of diverse groups of people.

This drawing shows people-young, old, rich, poor, disabled, a mother with a baby, a man smoking - as individuals who create community. Their hands holding up the stem of an umbrella represent the community and of people upholding a peaceful community. There is interdependence between the individual and the community and a process to create this community. The community itself can also be seen as 
peace - that we are upholding the peaceful community. The process is a long, long road. There's common ground that people can find, which is the belief in common values and the meeting of basic human needs.

3. Values. The drawing symbolizing peacebuilding values was a branching tree with deep roots in the ground and, above the tree, a dark cloud infused with lightning.

A lot of times we grow up with a certain set of values or assume we know what our values are. But then we find that conflicts arise when people whom we respect don't always act in accordance with what we perceive their values to be or our values are. When there is a gap between what we believe in and the actions or the behavior, conflict can occur within values. A lot of times people will hold certain values, but actually personal agendas are more important than anything else. We decided that the best [approach] was to take personal responsibility for our values and then link our actions to that. Respect was identified as an underlying value of peacebuilding-respect to say we all have different views and different perceptions. Basic needs are in the roots of the tree, and water-which all human beings need-is absorbed through the roots. Several stems of the tree represent diversity. What links the branches together, and therefore people, are values such as love, safety, justice, and respect.

4. Process. The group drawing of peacebuilding as a process shows a symbolic journey on a train. Depicted in the drawing are a road, a train, a clock, a ticket window, and a rainbow.

The road shows it is a journey we are on. People are involved in different parts of the journey. The initiative needs to be sustained, and there must be common understanding of what is involved. During the journey, the environment can change-for example, wet roads, the wind. A rainbow symbolizes seeking to reach our goal. Some people will want to get off the journey, others will join it. People do different tasks; some keep the engines going, others make sure there is fuel. Communication skills are needed and energy to keep going. The ticket window shows the need to buy into the process as part of the commitment. On the train, people will work and do different parts of peacebuilding; it is all linked. There is going to be conflict; what is important is dealing with the conflict.

\section{Analysis of Common Themes}

Examination of both drawings and participant narratives about them revealed common themes reflecting women's perspectives on peacebuilding. Each drawing showed common and familiar objects. All had dynamic growth or movement functions, or both, indicating an active principle. Outcomes were illustrated symbolically and were pragmatic: shelter, the end of a journey, securing food. 
Drawings all showed interdependent processes and functions and preferences for "heart expression" (emotional) as more prominent than "head expression" (cognitive). Two of the drawings used organic symbols (maize, tree) whereas the other two showed objects built for human use (train/road, umbrella). The cultural context of women's lives in South Africa is made evident in the drawings by the variety of people's skin colors, occupations, values, and basic human needs.

Significant for our study, all drawings emphasized psychosocial processes as paramount in women's peacebuilding. Process-oriented peacebuilding, described as collaborative and collective, involves team building, requires a leap of faith and trust in the process, gives confidence to explore, changes one's world view, deals with emotions and related values, touches the heart, and requires being involved. Furthermore, a process orientation raises questions such as: (a) Do we incorporate these processes in our own lives? (b) What motivates us? and (c) Where does our understanding of peacebuilding come from? Several participants found that the process of drawing was a peacebuilding exercise in itself, because it gave them the opportunity to practice peacebuilding in their search for a common understanding and their work toward a common goal.

\section{DISCUSSION}

For this group of South African women, the most striking finding was the extent to which peacebuilding was viewed as highly psychological, emphasizing processes, behaviors, values and attributes. Participants' perspectives were holistic, and peacebuilding was seen as closely interrelated to physical, psychological, and spiritual health. The term peacebuilding, rather than having a delimited meaning, is a broad sweep of processes and pragmatic initiatives bringing people together. Common methods used in peacebuilding are collaboration, advocacy, and networking. Workshop participants recognized that their peacebuilding initiatives were marginalized because they lack power and voice, and that they themselves fail to recognize that what they do is often distinct, but just as important, as what men do to build peace.

These South African women also recognized the interdependence of peacebuilding and other peace-related activities - peace enforcement, peacekeeping, and peacemaking. Whereas peacemaking and peacebuilding were identified as having strong process orientations, they considered themselves to be marginalized within peacekeeping and peace enforcement. Some participants realized that they had not recognized their own involvement in peacekeeping and peace enforcement "because we don't do it like men." An example given of a distinct peacekeeping approach by women was going into shebeens (community gathering places for men's drinking) to monitor and prevent violence. 
Power, or lack of it, was critically important to these women. They recognized that women possess incredible power to influence peace processes and yet lack efficacy in using it. Also, they knew that the power they possess and their access to it differed from men. For example, women might more readily wield their power through NGOs or distinct women's practices such as withdrawing marital rights, going on strike, or bashing pans outside homes when domestic abuse is occurring. They recognized the importance of "raising their voices" more frequently, protesting, and "using their voices" within peace processes. "Giving voice" was viewed as important, especially to women who live in cultures where religious beliefs require that they submit to men.

Participants felt marginalized within power structures of the state, regional, and international bodies. They realized that although community-based peacebuilding is important, they must work at all levels and make a special effort to involve themselves in macro and formal peacebuilding structures so that women's perspectives are integrated within mainstream peace processes (Lazarus \& Taylor, 1999). Women have yet to gain power in mainstream venues but are being propelled through the impetus of women organizing globally and the strategies put forth in documents such as the PFA and the Machel Study (UN, 1996a, 1996b). Not only must women gain political power, but they must also transform political structures and processes into more democratic and egalitarian forms (Anderson, 1999). At the time of the workshop in 1998, South Africa was ranked seventh in the world on an index of women in government, with women constituting $27 \%$ of members of parliament in the national government (Van Donk \& Maceba, 1999). Although these numbers are dramatically better than during apartheid, women are still under-represented in parliament and decision-making structures (Zulu, 1998). Yet, as discussed by Breines of UNESCO's Culture of Peace program, internationally women constitute only $1 \%$ of elected heads of state and governments, $7 \%$ of government ministers (few of whom are in ministries of foreign affairs, defense, the interior, or finance), and about $11 \%$ of parliamentarians (Breines, 1999). Only the Nordic countries have a critical mass of women who have served for some years in both parliament and government. Women also do not yet comprise a critical mass in policy-making venues such as industry and finance, the armed forces, and major religious bodies (Breines, 1999).

Women's political power often emerges from women's networks, especially as these groups become international in scope. Keck and Sikkink (1998) traced the popularization of modern use of the word network as originating from the notion of the "old boys" network, whereby men often furthered professional goals through exclusive men-only clubs. Women subsequently imitated and innovated the network model so that now, more than any other group, women's organizations use the terms network and networking to describe their interactions and often eschew rigid hierarchy and embrace egalitarian processes. 
Christie (1997) argued that a just and sustainable peace requires equitable satisfaction of human needs for security, identity, well-being and self-determination. Peacebuilding, according to a human needs perspective, would not be driven by conflicts and violence but by social transformation. Christie's argument was supported by workshop participants' discourse. A prominent theme was that peacebuilding concerns meeting basic needs, which were described as "food for the nation" and "bedrock." The fundamental importance of meeting basic human needs was explicitly detailed in three of the four drawings. The drawings showed that when basic needs are not met, deprivation and death occur in spiritual and physical senses - and the bases for wars are created.

The centrality of individual and community values was a theme throughout the workshop and intersected with discussions of peacebuilding processes. Whereas values of honesty, love, truth, justice, integrity, and respect were identified, enabling these values to flourish was seen as contingent on processes of communication, support, listening, respect, and understanding. Lederach (1995a, 1995b), although lacking a gender perspective in his analysis, has been prominent in linking the interconnection between values and peacebuilding practices. Mayton, Diessner, and Granby (1996) studied the relation between nonviolence and human values. The values identified in their study (e.g., universalism, benevolence, conformity) did not contain the specificity about personal values that women in our study discussed as intrinsic to peacebuilding processes. Research about how values may influence peacebuilding processes and the gendered nature of values is an important area for future inquiry.

To our knowledge, this study represents a first systematic effort to learn how women view peacebuilding within their own country and culture. Replications in other countries and cross-cultural comparisons would improve our understanding of practices and processes women hold in common and those that are culturally distinct. In turn, this information could provide a basis for model development and training. Aside from our findings, a pragmatic outcome of this workshop was the building of a network of South African women peacebuilders who share common meanings of peacebuilding and have identified processes and methods they can use.

\section{ACKNOWLEDGMENTS}

We thank Necla Tschergi of the International Development Research Centre in Ottawa, Ontario, for her sustaining interest in the project. The University of Wyoming International Office provided travel support during the planning phases of this project. We wish to express our appreciation to Michael Wessells, United States of America, for his helpfulness as program evaluator. In South Africa, Nomfundo Walaza and Joanne Sullivan expertly facilitated the workshop, and Ghalib Galant, 
Vivien Harber, and Naomi Tutu gave generously of their time as members of the Advisory Panel. Also Lynn de Villers and Phillippa Druiff, University of Cape Town Department of Psychology, provided important project assistance.

\section{REFERENCES}

Abu-Saba, M. (1999). Human needs and women peacebuilding in Lebanon. Peace and Conflict: Journal of Peace Psychology, 5, 37-51.

Anderlini, S. (2000). Women at the peace table: Making a difference. New York: United Nations Development Fund for Women.

Anderson, S. (1999). Women's many roles in reconciliation. In H. van de Veen (Ed.), People building peace: Inspiring stories from around the world (pp. 230-236). Utrecht: European Centre for Conflict Prevention.

Boulding, E. (1995). Feminist inventions in the art of peacemaking: A century overview. Peace and Change, 20, 408-438.

Breines, I. (1999). A gender perspective on a culture of peace. In I. Breines, D. Gierycz, \& B. Reardon (Eds.), Towards a women's agenda for a culture of peace (pp. 33-56). Paris: UNESCO Publishing.

Christie, D. (1997). Reducing direct and structural violence: The human needs theory. Peace and Conflict: Journal of Peace Psychology, 3, 315-332.

de la Rey, C., \& McKay, S. (in press). Peace as a gendered process: Perspectives of women doing peacebuilding in South Africa. Peace and Conflict Studies.

Fisher, R. (1993). The potential for peacebuilding: Forging a bridge from peacekeeping to peacemaking. Peace and Change, 18, 247-266.

Fitzduff, M. (1999). Changing history: Peacebuilding in Northern Ireland. In H. van de Veen (Ed.), People building peace: Inspiring stories from around the world (pp. 87-103). Utrecht: European Centre for Conflict Prevention.

Galtung, J. (1976). Three approaches to peace: Peacekeeping, peacemaking, and peacebuilding. In J. Galtung, Peace, war and defense: Essays on peace research (Vol. 1). Copenhagen: Christian Zjiers.

Goldblatt, B., \& Meintjes, S. (1998). South African women demand the truth. In M. Turshen \& C. Twagiramariya (Eds.), In wartime: Gender and conflict in Africa (pp. 27-61). London: Zed Books.

Hall, B. (1992). From margins to center? The development and purpose of participatory research. The American Sociologist, 23, 15-28.

International Alert. (2000, May). Women, violent conflict and peacebuilding: Global perspectives. London: Author.

Keck, M., \& Sikkink, K. (1998). Activists beyond borders. Ithaca, NY: Cornell University Press.

Lazarus, A., \& Taylor, C. (1999). Women and peacebuilding. Agenda: Empowering Women for Gender Equality, 40, 91-94.

Lederach, J. P. (1995a). Building peace: Sustainable reconciliation in divided societies. Tokyo: United Nations University.

Lederach, J. P. (1995b). Preparing for peace. Syracuse: Syracuse University Press.

Machel, G. (2000, September). The Machel Review Document, the impact of armed conflict on children: Four years later. Background Papers: The International Conference on War-Affected Children. Winnipeg, Canada: International Conference on War-Affected Children.

Mayton, D., Diessner, R., \& Granby, C. (1996). Nonviolence and human values: Empirical support for theoretical relationships. Peace and Conflict: Journal of Peace Psychology, 2, 245-253.

Mazurana, D., \& McKay, S. (1999). Women and peacebuilding. Montreal: International Center for Human Rights and Democratic Development. 
McKay, S. (1996). Gendering peace psychology. Peace and Conflict: Journal of Peace Psychology, 2, 93-107.

McKay, S. (1998). The impact of armed conflict on girls and women. Peace and Conflict: Journal of Peace Psychology, 4, 381-392.

McKay, S., \& Mazurana, D. (2001). Raising women's voices for peacebuilding: Vision, impact and limitations of media technologies. London: International Alert.

McKay, S., \& Winter, D. D. (1998). The United Nations Platform for Action: Critique and implications. Peace and Conflict: Journal of Peace Psychology, 4, 167-178.

Pillay, A. (2000). Coalition-building for peace in Africa. Agenda: Empowering Women for Gender Equality, 43, 32-35.

Reason, P. (1998). Co-operative inquiry as a discipline of professional practice. Journal of Interprofessional Care, 12, 419-436.

Reinharz, S. (1992). Feminist methods in social research. New York: Oxford University Press.

Rigby, A. (1994). Peace building in the occupied territories: The challenge of educational reform. Peace and Change, 19, 349-372.

Ruecker, K. (2000, January). Engendering peacebuilding: Case studies from Cambodia, Rwanda and Guatemala. Ottawa, Canada: Peacebuilding and Human Security Division, Department of Foreign Affairs and International Trade.

Turshen, M. (1998). Women's war stories. In M. Turshen \& C. Twagiramariya (Eds.), What women do during wartime: Gender and conflict in Africa (pp. 1-26). London: Zed Books.

United Nations. (1992). Agenda for peace. New York: Author.

United Nations. (1996a). Impact of armed conflict on children. New York: Author.

United Nations. (1996b). The platform for action and Beijing declaration. New York: Author.

Van Donk, M., \& Maceba, M. (1999). Women at the crossroads: Women in governance. Agenda, 40, $18-22$.

Wessells, M. (1992). Building peace psychology on a global scale: Challenges and opportunities. The Peace Psychology Bulletin, 1, 32-44.

Wessells, M. (1998). The changing nature of armed conflict and its implications for children: The Graça Machel/UN Study. Peace and Conflict: Journal of Peace Psychology, 4, 321-334.

Zulu, L. (1998). Role of women in the reconstruction and development of the new democratic South Africa. Feminist Studies, 24, 147-157. 